\title{
ANALISIS TENTANG HAK IMUNITAS HUKUM PROFESI ADVOKAT DALAM PENANGANAN KASUS PIDANA
}

\author{
Dita Tania Pratiwi, Manertiur Meilina Lubis
}

\begin{abstract}
Abstrak
Advokat adalah profesi hukum yang terhormat (officium mobile) dimana tata cara pekerjaannya diatur dalam Kode Etik Profesi Advokat dan Undang Undang Nomor 18 Tahun 2003 tentang Advokat. Dalam perwujudannya profesi tersebut ternyata tidak selalu berlangsung dengan sendirinya sebagai konsekuensi dari keyakinan pada pentingnya fungsi-fungsi itu, melainkan sangat dipengaruhi oleh berinteraksinya berbagai kekuatan kemasyarakatan. Dalam tulisan ini penulis akan membahas permasalahan mengenai etika profesi penegak hukum khusus nya profesi advokat sebagai kuasa hukum yang dikaitkan dengan hak imunitas kuasa hukum. Dewasa ini, permasalahan terkait hak imunitasi kuasa hukum mulai bermunculan kepermukaan. Pada awal tahun 2018, Fredrich Yunadi selaku mantan kuasa hukum Setya Novanto diduga melakukan perbuatan merintangi penyidikan korupsi dengan menyembunyikan barang bukti dari kasus elektronik KTP (e-KTP) yang diduga dilakukan oleh Setya Novanto. Penelitian ini bertujuan untuk mendapatkan fakta tentang seberapa besar kekebalan hukum yang dimiliki oleh seorang pemegang kuasa dari sebuah kasus dengan studi kasus e-KTP oleh Setya Novanto, tak hanya itu penelitian ini juga bertujuan untuk mengetahui kekuatan hak imunitas profesi advokat dalam menangani kasus pidana. Penelitian ini mengimplementasikan metode normatif di mana sumber analisa berasal dari teori-teori yang ada dalam pustaka dan undang-undang yang berlaku terkait dengan kasus ini.
\end{abstract}

Kata Kunci: Advokat, Hak Imunitas, Penegak Hukum Pidana

\begin{abstract}
Advocate is an officium nobile whom the procedure of the legal service is ruled by the ethics code and of this profession and Law Number 18 of 2003 on Advocate. In fact, Advocate is not only organised by himself as the consequence of those function, but also depends on the other social interplays. In this paper, the author will discuss some issues regarding the ethics of the law enforcement profession, especially the advocate profession as a legal representative associated with the legal rights immunity as the issues related to the legal rights of immunization rights began to surface. In mid of 2018, Friedrich Yunadi as a former advocate of Setya Novanto was suspected of carrying out an act of obstructing a corruption investigation by hiding evidence from an electronic KTP (e-KTP) case allegedly carried out by Setya Novanto. This study aims to obtain facts about how much
\end{abstract}


impunity possessed by a power of advocate from a Novanto case. This research applies a normative method in which the source of analysis comes from the theories gathered from literatures and applicable laws relating to this case.

Keywords: Advocates, Immunity Rights, Criminal Law Enforcement

\section{PENDAHULUAN}

Undang-Undang Dasar Negera Republik Indonesia Tahun 1945 menegaskan dalam Pasal 1 ayat (1) bahwa Negara Indonesia ialah negara kesatuan yang berbentuk republik. Pasal 1 ayat (2) menentukan bahwa kedaulatan rakyat berada di tangan rakyat dan dilaksanakan menurut Undang-Undang Dasar. ${ }^{1}$ SedangkanPasal 1 ayat (3) menentukan bahwa Negara Indonesia adalah negara hukum.Ketiga ayat dalam Pasal 1 UUD 1945 tersebut menunjukkan bahwa NegaraIndonesia merupakan negara kesatuan yang berbentuk republik, kedaulatan berada di tangan rakyat dan berdasarkan hukum (rechtstaat) bukan berdasarkan atas kekuasaan belaka (machtstaat) ${ }^{2}$

Sebagai negara hukum, baik penguasa maupun rakyat atau warga negara, bahkan negara itu sendiri semuanya harus tunduk kepada hukum. Semua sikap, tingkah laku, dan perbuatannya harus sesuai atau menurut hukum. Sumber hukumnya adalah rasa hukum yang terdapat di dalam masyarakat itu sendiri.Menurut Plato penyelenggaraan negara yang baik adalah pemerintahan yang didasarkan pada pengaturan hukum yang baik, dan penyelenggaraan pemerintahan Sebagai negara hukum, baik penguasa maupun rakyat atau warganegara, bahkan negara itu sendiri semuanya harus tunduk kepada hukum. ${ }^{3}$ Semua sikap, tingkah laku, dan perbuatannya harus sesuai atau menurut hukum. Sumber hukumnya adalah rasa hukum yang terdapat di dalam masyarakat itu sendiri.Menurut Plato penyelenggaraan negara yang baik adalah pemerintahan yang didasarkan pada pengaturan hukum yang baik, dan penyelenggaraan pemerintahan. ${ }^{4}$

\footnotetext{
${ }^{1}$ Indonesia, Pasal 1 ayat 2 Undang-Undang Dasar Negara Republik Indonesia Tahun 1945

2 ibid.,Pasal 1 ayat 3

${ }^{3}$ Soehino, Ilmu Negara, (Yogyakarta:Liberty ,1996 ), hal.200.

${ }^{4}$ Ibid, hal. 160.
} 
Negara Indonesia sebagai negara hukum yang merdeka harus membangun hukum nasionalnya sendiri yang bercirikan kepada watak dan jiwa kepribadian (volkgeist) bangsa Indonesia. Hukum tidak berlaku secara universal, karena hukum itu lahir dari "volkgeist" yang berbeda-beda antara bangsa yang satu dengan bangsa lainnya. Hukum nasional Indonesia merupakan hukum dalam lingkup nasional yang dibangun dari hasil usaha bangsa Indonesia yang berlandaskan dan berpedoman pada dasar falsafah dari ideologi Pancasila. ${ }^{5}$ Sistem peradilan pidana (criminal justice system) merupakan suatu usaha untu memahami serta menjawab pertanyaan apa tugas hukum pidana di masyarakat, bukan sekedar bagaimana hukum pidana di dalam undang-undang dan bagaimana hakim menerapkannya. ${ }^{6}$ Setelah berlakunya Undang-Undang Republik Indonesia Nomor 8 Tahun 1981 tentang Hukum Acara Pidana (KUHAP), system peradilan pidana di Indonesia mempunyai 4 sub sistem yaitu , sub sistem kepolisian , Kejaksaan, Pengadilan, dan Sub sistem Lembaga Masyarakat ${ }^{7}$.

Setelah Undang-Undang Republik Indonesia Nomor 18 Tahun 2003 tentang Advokat berlaku, di antara keempat sub sistem peradilan pidana tersebut terdapat unsur advokat (dengan berbagai istilahnya) yang mempunyai peranan sangat penting dalam sistem peradilan pidana di Indonesia. Hal itu dapat dilihat dalam Pasal 54 dan 56 Undang-Undang Republik Indonesia Nomor 8 Tahun 1981 tentang Hukum Acara Pidana. Bahwa pada pasal 54 menyatakan :

"Guna kepentingan pembelaan, tersangka atau terdakwa berhak mendapat bantuan hukum dari seorang atau lebih penasihat hukum selama dalam waktu dan pada setiap tingkat pemeriksaan, menurut tata cara yang ditentukan dalam undang-undang ini"

Pasal 56 ayat (1):

"Dalam hal tersangka atau terdakwa disangka atau didakwa melakukan tindak pidana yang diancam dengan pidana mati atau ancaman pidana lima belas tahun atau lebih atau bagi mereka yang tidak mampu yang diancam dengan pidana lima tahun atau lebih yang tidak mempunyai

\footnotetext{
${ }^{5}$ Ibid, hal.121.

${ }^{6}$ Zainal Abidin Farid, Hukum Pidana, (Jakarta: Sinar Grafika, 1998), hal. 25.

7 Indonesia, Undang-Undang Republik Indoneisa Nomor 8 Tahun 1981 tentang Hukum Acara Pidana
} 
penasihat hukum sendiri, pejabat yang bersangkutan pada semua tingkat pemeriksaan dalam proses peradilan wajib menunjuk penasihat hukum bagi mereka"

Profesi advokat atau pengacara memiliki satu hak privilege (hak istimewa) berupa imunitas (kekebalan hukum), tidak dapat dituntut baik secara perdata ataupun pidana dalam melakukan tugasnya baik di dalam maupun di luar pengadilan dengan iktikad baik. Frasa ini memperjelas imunitas advokat, namun juga mempertegas kewajiban dan tanggung jawab moral yang seimbang. ${ }^{8}$ Bahwa definisi advokat adalah orang yang melakukan suatu pekerjaan berdasarkan keahlian (knowledge), untuk melayani masyakarat secara independen dengan limitasi kode etik yang ditentukan oleh komunitas profesi. Pasal 16 UndangUndang Republik Indonesia Nomor 18 Tahun 2002 tentang Advokat berbunyi: ${ }^{9}$ "Advokat tidak dapat dituntut baik secara perdata maupun pidana dalam menjalankan tugas profesinya dengan itikad baik untuk pembelaan klien dalam sidang pengadilan." Dalam penjelasan pasal tersebut dijelaskan, bahwa yang dimaksud dengan itikad baik adalah menjalankan tugas profesi demi tegaknya keadilan berdasarkan hukum untuk membela kepentingan kliennya. Yang dimaksud dengan sidang pengadilan adalah sidang pengadilan dalam setiap tingkat pengadilan di semua lingkungan peradilan.

Amar Putusan Mahkamah Konstitusi Republik Indonesia Nomor 26/PUUXI/2013 menyatakan, bahwa Pasal 16 Undang-Undang Republik Indonesia Nomor 18 Tahun 2013 tentang Advokat (Lembaran Negara Republik Indonesia Tahun 2003 Nomor 49, Tambahan Lembaran Negara Republik Indonesia Nomor 4288) tidak mempunyai kekuatan hukum mengikat sepanjang tidak dimaknai, "Advokat tidak dapat dituntut baik secara perdata maupun pidana dalam menjalankan tugas profesinya dengan itikad baik untuk kepentingan pembelaan klien di dalam maupun di luar sidang pengadilan”. Pengertian Luar sidang dalam putusan MK itu adalah pembelaan advokat sejak kliennya diperiksa dan ditersangkakan diluar persidangan.

\footnotetext{
${ }^{8}$ Zainal Abidin Arifin.,Op Cit,.hal.30.

${ }^{9}$ Indonesia, Undang-Undang Republik Indonesia Nomor 18 Tahun 2002 Tentang Advokat.
} 
Susanti Adi Nugroho berpendapat bahwa imunitas advokat tidak dapat diberikan secara mutlak. Advokat tidak kebal hukum sehingga ia tetap dapat dimintakan pertanggungjawabannya. Terlebih lagi, advokat adalah profesi yang sifatnya profesional dan klien berhak mendapatkan upaya terbaik dari seorang advokat. Frasa "dalam persidangan" ini adalah tidak hanya dalam ruang persidangan itu sendiri, tetapi setiap tindakan yang diperlukan saat melakukan proses persidangan itu sendiri, baik di pengadilan tingkat pertama hingga peninjauan kembali. Tindakan coorparate lawyer dalam menangani urusan kliennya sama sekali tidak bersinggungan dengan proses pengadilan. Pendapat hukum mengenai urusan kliennya tidak dapat dikategorikan sebagai pendapat hukum yang kebal hukum sebagaimana diatur dalam Pasal 14, Pasal 16, dan Pasal 18 Undang-Undang Republik Indonesia Nomor 18 Tahun 2003 tentang Advokat. Apabila terjadi kesalahan saat memberikan pendapat hukumnya, mereka dapat dimintai pertanggungjawaban. Dengan kata lain tidak dilindungi oleh hak imunitas. ${ }^{10}$

Hak imunitas advokat belakangan ini sering kali disalah artikan dalam hal mana diartikan seolah-olah semua tindakan yang dilakukan oleh advokat untuk kepentingan klien dilindungi undang-undang dan juga tidak dapat dituntut pertaanggungjawabannya secara hukum. Pemahaman mengenai hak imunitas advokat, pada dasarnya terkait dengan latar belakang dari pertanyaan mendasar mengenai alasan advokat harus dilindungi dengan suatu imunitas. Alasan mendasar advokat diberikan perlindungan hak imunitas adalah karena dalam membela kliennya mereka tidak boleh dikenai hukuman pidana, perdata, dan administratif selama pembelaan yang mereka lakukan tanpa melanggar hukum. ${ }^{11}$

Di dalam kasus yang ingin di teliti bahwa terjadi pelanggaran hak imunitas advokat Fredrich Yunadi yaitu mantan pengacara Setya Novanto ditetap sebagai tersangka dan ditahan Komisi Pemberantasan Korupsi (KPK).Komisi antirasuah menilai Fredrich telah menghalangi dan merintangi penyidikan kasus e-KTP dengan tersangka Novanto. Hal ini merujuk pada dugaan KPK tentang

\footnotetext{
10 Teguh Prasetyo , Hukum dan Sistem Hukum Berdasarkan Pancasil,(Yogyakarta:Media Perkasa,2013), hal.34.

${ }^{11}$ Keadilan Bermartabat Perspektif Teori Hukum, (Bandung;Nusa Media,2015), hal.60.
} 
adaanya persengkokolan antara Fredrich Yunadi dna Bimanesh Sutarjo, seorang dokter RS Medika Permata Hijau, yang bekerja sama untuk memanipulasi datadata medis Setya Novanto saat dirawat setelah kecelakaan yang menimpa mantan Ketua DPR itu. Dalam hal ini Fredrich mengklaim bahwa dirinya dikriminalisasi karena sebagai advokat ia memiliki hak imunitas, sementara KPK menemukan bukti kuat jika Fredrich dan Bimanesh terlibat persengkokolan menghalangi penyidikan. Disamping itu KPK yakin bahwa advokat menyadari isi ketentuan tentang Pasal 21 Undang-Undang Nomor 31 tahun 1999 tentang Tindak Pidana Korupsi , yang disangkakan kepada Fredrich yaitu karena sebagai pihak yang paham hukum, perbuatan menghalang-halangi penanganan kasus korupsi jelas sekali ada ancaman pidananya. Dengan isi pasal 21 adalah "Setiap orang yang dengan sengaja mencegah, merintangi, atau menggagalkan secara langsung atau tidak langsung penyidikan, penuntutan, dan pemeriksaan di sidang pengadilan terhadap tersangka dan terdakwa ataupun para saksi dalam perkara korupsi, dipidana dengan pidana penjara paling singkat 3 tahun dan paling lama 12 tahun dan atau denda paling sedikit Rp150 juta dan paling banyak Rp600 juta."

Dengan demikian hak imunitas advokat ini hanya berlaku bagi mereka yang menjalankan profesinya dalam membela kliennya dengan itikad baik. Ukuran itikad baik ini adalah sesuai dengan perundang-undangan yang berlaku dan tidak melanggar hukum. Dengan berdasarkan Kode Etik Advokat seorang pengacara dalam menjalankan profesinya harus bebas dan mandiri, serta tidak dipengaruhi oleh siapapun dan wajib memperjuangkan hak-hak asasi manusia. Ahli Hukum Pidana Abdul Fickar Hajar juga mengatakkan hak imunitas advokat hanya diberikan kepada pengacara yang membela kliennya dengan itikad baik, bukan menghalang-halangi proses hukum.

\subsection{RUMUSAN MASALAH}

1.Bagaimanakah kekuatan hak imunitas profesi advokat dalam penanganan kasus pidana (studi kasus : Fredrich Yunadi)?

2. Bagaimanakah hak imunitas advokat ditinjau dari pengaturan hukum positif di Indonesia? 


\subsection{TUJUAN PENULISAN}

a. Untuk mengetahui kekuatan hak imunitas profesi advokat dalam penangan kasus pidana Fredrich Yunadi

b. Untuk dapat mengetahui kekutan hak imunitas profesi advokat dalam penanganan kasus pidana ditinjau dari pengaturan hukum positif di Indonesia.

\subsection{METODE PENELITIAN}

\section{Jenis Penelitian}

Jenis penelitian dalam penelitian hukum ini adalah penelitian hukum normatif. Menurut Terry Hutchinson sebagaimana dikutip Peter Mahmud Marzuki mendefinisikan bahwa penelitian hukum doktrinal adalah sebagai berikut $:^{12}$

"doctrinal research: research wich provides a systematic exposition of the rules goverming a particular legal kategory, analyses the relationship between rules, explain areas of difficullty and, perhaps, predicts future development."

Penelitian hukum normatif adalah disebut sebagai penelitian perpustakaan atau studi dokumen karena penelitian ini dilakukan atau ditujukan hanya pada peraturanperaturan yang tertulis atau bahanbahan hukum yang lain. Pada intinya penelitian yang dilakukan dengan cara meneliti bahan-bahan pustaka atau data sekunder yang terdiri dari bahan hukum primer, bahan hukum sekunder dan bahan hukum tertier. ${ }^{13}$

\section{Teknik Pengumpulan Data}

Adapun teknik pengumpulan data yang dilakukan penulis adalah dengan: ${ }^{14}$

1. Teknik kepustakaan (library research) yakni suatu metode yang digunakan dengan jalan mempelajari melalui studi buku

12 Peter Mahmud Marzuki,Penelitian Hukum,(Jakarta:Kencana Prenada Media Group,2011), hal.39.

${ }^{13}$ Ibid,hal.40.

14 Abdulkadir Muhammad,Hukum dan Penelitian Hukum, (Bandung:PT Citra Aditya Bakti,2004),hal.57. 
literatur, perundang-undangan dan bahan-bahan tertulis lainnya yang berhubungan dengan materi pembahasan yang digunakan untuk mendukung pembahasan ini. Dengan cara membaca, mempelajari buku-buku, hasil penelitian, tulisan-tulisan dan peraturan perundang-undangan yang terkait.

2. Teknik wawancara dengan pihak yang terkait yang berhubungan dengan penelitian ini.

\section{Jenis dan Sumber Data}

Adapun jenis dan sumber yang akan dipergunakan dalam penulisan ini meliputi : ${ }^{15}$

1. Data Primer

Data primer adalah data yang diperoleh secara langsung dari lapangan. Melalui wawancara dengan sumbernya dan/atau narasumber yang terkait dengan kasus tindak pidana korupsi.

2. Data Sekunder

Data sekunder adalah data penelitian yang diperoleh penulis secara tidak langsung melalui media perantara yang diperoleh dan dicatat oleh pihak lain serta bahan lain yang digolongkan sebagai berikut.

a. Bahan Hukum Primer:

Merupakan bahan hukum yang berasal dari peraturan perundang-undangan dan ketentuan peraturan yang ada di Indonesia.

1) Undang-undang Dasar Negara Republik Indonesia tahun 1945

2) Undang-undang Nomor 18 tahun 2003 Tentang Advokat

3) Kitab Undang-Undang Hukum Pidana (wetboek van strafrecht)

15 Soerjono Soekanto dan Sri Mamudji,Penelitian Hukum Normatif, Cetakan ke-8, (Jakarta:Raja Grafindo Persada,2004),hal.14. 
4) Undang-undang Nomor 8 Tahun 1981 tentang Kitab Undang-undang Hukum Acara Pidana

b. Bahan Hukum Sekunder

Bahan hukum sekunder, yaitu yang memberikan penjelasan mengenai bahan hukum primer seperti, rancangan undang-undang, hasil-hasi penelitian, hasil karya dari kalangan hukum dan seterusnya. Yang menjadi bahan hukum sekunder dalam penulisan ini adalah buku-buku, makalah atau literatur yang berkaitan atau membahas tentanng hukum acara pidana, hukum pidana.

\section{Teknik Analisis Bahan Hukum}

Menurut Peter Mahmud Marzuki yang mengutip pendapat Philipus M.Hadjon memaparkan metode deduksi sebagaimana silogisme yang diajarkan oleh Aristoteles. Penggunaan metode deduksi berpangkal dari pengajuan premis mayor (pernyataan yang bersifat umum). Kemudian diajukan premis minor (bersifat khusus), dari kedua premis itu kemudian ditarik suatu kesimpulan atau conclusion. Akan tetapi di dalam argumentasi hukum, silogisme hukum tidak sesederhana silogisme tradisional. Penelitian ini menggunakan teknik analisis data dengan logika deduktif, logika deduktif atau pengolahan bahan hukum dengan cara deduktif yaitu menjelaskan suatu hal yang bersifat umum kemudian menariknya menjadi kesimpulan yang lebih khusus. ${ }^{16}$

\section{Metode Pendekatan}

Keterkaitannya dengan penelitian normatif, pendekatan yang digunakan dalam penulisan hukum menurut Peter mahmud Marzuki adalah sebagai berikut: ${ }^{17}$

1. Pendekatan perundang-undangan ( statute pproach )

2. Pendekatan kasus ( case approach )

16 Peter Mahmud Marzuki, Penelitian Hukum, Edisi Revisi, (Jakarta: Kencana Media Group,2006), hal.134.

${ }^{17}$ Peter Mahmud Marzuki, Op Cit,.hal.136. 
3. Pendekatan historis ( historical approach )

4. Pendekatan perbandingan ( Comparative approach )

5. Pendekatan konseptual ( conceptual approach )

Adapun pendekatan yang digunakan penulis dari atan diatas adalah pendekatan perundang-undangan (statute approach) dan pendekatan kasus (The Case Approach). Pendekatan perundanganundangan adalah pendekatan yang dilakukan dengan menelaah semua undang-undang dan regulasi yang bersangkut paut dengan isu hukum yang ditangani. Pendekatan kasus adalah pendekatan yang dilakukan dengan cara melakukan telaah terhadap kasus-kasus yang berkaitan dengan isu yang dihadapi yang telah menjadi putusan pengadilan yang telah mempunyai kekuatan hukum yang tetap.

\section{PEMBAHASAN}

1. Kekuatan hak imunitas profesi advokat dalam penanganan kasus pidana (studi kasus : Fredrich Yunadi).

Hak imunitas pada profesi advokat sebenarnya bukan hal yang baru lagi. Namun, yang menjadi menarik adalah perkembangan dari hak imunitas itu sendiri. Pada awalnya hak imunitas advokat mengacu pada Pasal 16 Undang-Undang No 18 Tahun 2003 tentang Advokat bahwa advokat tidak dapat dituntut baik secara perdata maupun secara pidana dalam menjalankan tugas profesinya dengan iktikad baik untuk pembelaan klien dalam sidang pengadilan. ${ }^{18}$ Berkaitan dengan hak imunitas ini sudah terjadi berbagai kasus dengan tafsir berbeda oleh Majelis Hakim. Salah satu contohnya adalah kasus yang terjadi pada awal 2018 yaitu kasus Fredrich Yunadi dalam penanganan perkara diduga Setya Novanto melakukan korupsi Elektronik KTP (E-KTP).

Fredrich Yunadi pada saat itu merupakan kuasa hukum Setya Novanto, dijatuhkan vonis penjara tujuh tahun oleh Pengadilan Tipikor Jakarta akibat perbuatannya merintangi penyidikan korupsi yang di duga dilakukan oleh Setnov. Ia kena batu akibat tindak-tanduknya saat mendampingi Setnov yang

18 R.I. Undang-undang nomor 8 tahun 2008 tentang advokat pasal 16 
saat itu masih kliennya yang telah ditetapkan sebagai tersangka korupsi eKTP oleh KPK. Ketika KPK sedang mencari Setnov, pria yang saat itu masih Ketua DPR itu disebut mengalami kecelakaan di kawasan Permata Hijau, Jakarta Selatan, 16 November 2017 petang.

Akibat kecelakaan mobil yang dikemudikan Hilman Mattauch (kala itu berstatus kontributor stasiun televisi berita), Setnov dilarikan ke RS Medika Permata Hijau yang jaraknya sekitar 1 kilometer dari lokasi kecelakaan. Kepada wartawan di rumah sakit sesaat setelah kecelakaan Fredrich menyatakan luka kliennya sebesar Bakpao. Dia pun melakukan adu argumen dengan tim KPK yang dikirim ke rumah sakit tersebut untuk melakukan pengecekan perihal kondisi kesehatan Setnov. Alhasil, Fredrich tak bisa menahan langkah KPK, dan Setnov dipindahkan ke Rumah Sakit dr. Cipto Mangunkusumo, Jakarta Pusat, untuk dilakukan pembantaran. Ketika Setnov dinyatakan sehat oleh dokter di RSCM, ia dibawa ke markas KPK dan ditahan di sana setelah diperiksa lebih lanjut. Fredrich tampak terlihat ikut mendampingi Setnov pada malam itu.

Sekitar sebulan kemudian, Fredrich diamankan KPK sebagai tersangka merintangi penyidikan korupsi e-KTP yang menjerat Setnov. Ia tak sendirian, karena bersama dirinya ditangkap pula dokter yang menangani Setnov di RS Medika Permata Hijau, Bimanesh Sutarjo.

Usai diperiksa penyidik KPK, Fredrich yang mengenakan rompi oranye itu menyatakan bahwa dirinya tidak bisa ditahan KPK karena hanya menjalankan tugas profesi sebagai advokat. "Saya difitnah katanya melakukan pelanggaran, sedangkan Pasal 16 Undang-Undang 18 tahun 2003 tentang Advokat, sangat jelas menyatakan advokat tidak dapat dituntut secara perdata maupun pidana," kata Fredrich, Sabtu (13/1/2018).

Selama menjalani persidangan, Fredrich Selama menjalani persidangan, Frederich selalu membuat tingkah yang membuat geram jaksa. Salah satunya saat pemeriksaan saksi dokter dari RS Medika Permata Hijau. Jaksa tak terima dengan sikap Fredrich meletakkan jari telunjuk di dahi yang dikaitkan dengan gila. Mantan kuasa hukum Setya Novanto ini juga pernah mengacungkan jari ke arah jaksa penuntut umum KPK dengan berbicara 
dengan nada tinggi. Frederich merasa tidak terima dengan jaksa yang ingin memutar bukti rekaman video pengawas (CCTV) RS Medika Permata Hijau.

Menurut Sekretaris Komisi Pengawas Perhimpunan Advokat Indonesia (Peradi) Victor W. Nadapdap mengatakan, hak imunitas advokat ini memang diatur dalam Pasal 16 UU Advokat, diperkuat dengan putusan Mahkamah Konstitusi (MK) yang menyatakan bahwa hak imunitas ini berlaku, baik di dalam maupun di luar persidangan.

Menurut pernyataan Victor mantan pengacara Novanto itu. Di satu sisi, mengklaim bahwa dirinya dikriminalisasi karena sebagai advokat ia memiliki hak imunitas. Sementara di lain sisi, KPK menemukan adanya bukti kuat jika Fredrich dan Bimanesh terlibat persekongkolan menghalangi penyidikan kasus e-KTP. ${ }^{19}$

Ahli Hukum Pidana dari Universitas Trisakti, Abdul Fickar Hajar juga mengatakan hal yang sama. Menurut dia, hak imunitas advokat hanya diberikan kepada pengacara yang membela kliennya dengan iktikad baik, bukan menghalang-halangi proses hukum.

Hal ini sesuai dengan putusan Mahkamah Konstitusi yang menyatakan Pasal 16 UU Advokat bertentangan dengan UUD 1945 dan tidak memiliki kekuatan hukum mengikat sepanjang tidak dimaknai: “Advokat tidak dapat dituntut baik secara perdata maupun pidana dalam menjalankan tugas profesinya dengan iktikad baik untuk kepentingan pembelaan klien di dalam maupun di luar sidang."

Sedangkan, penjelasan Pasal 16 UU Advokat menyatakan,"Yang dimaksud dengan “itikad baik" adalah menjalankan tugas profesi demi tegaknya keadilan berdasarkan hukum untuk membela kepentingan Kliennya. Yang dimaksud dengan "sidang pengadilan" adalah sidang pengadilan dalam setiap tingkat pengadilan di semua lingkungan peradilan." 20

Dalam hal ini, imunitas advokat selalu dibatasi oleh iktikad baik, yang didefinisikan dalam Penjelasan Pasal 16 UU Advokat, yaitu yang dimaksud

19 Abdul Aziz, "Melihat Hak Imunitas Advokat dalam Kasus Fredrich Yunadi", www.tirto.id, diakses tanggal 19 September 2019.

20 Agus Sahbani, “Akhirnya, Advokat Dapat Perlindungan di Luar Sidang”, www.hukumonline.com, diakses tanggal 19 September 2019. 
dengan iktikad baik adalah menjalankan tugas profesi demi tegaknya keadilan berdasarkan hukum untuk membela kepentingan klien.

Iktikad baik yang bersifat objektif dalam hal ini adalah sebuah tindakan harus berpedoman pada norma kepatutan, yaitu pada apa yang dianggap patut pada masyarakat. Dalam perspektif subjektif artinya pada kejujuran dan sikap batin seorang advokat saat melakukan tugasnya. ${ }^{21}$

Jika mengacu pada pemahaman di atas, justru di antara obstruction of justice dan hak imunitas advokat memiliki kesamaan unsur dalam irisannya, yakni adalah sama-sama memedomani dan memegang teguh tegaknya hukum dan fungsi peradilan baik formal maupun materiil. Secara logika, jika dua hal yang memiliki unsur sama bertentangan artinya bahwa ada salah satu yang salah.

Obstruction of justice mudah diverifikasi jika obstrasuction of justice dan iktikad baik telah memiliki kesamaan, yaitu pada komitmen penegakan hukum. Obstruction of justice adalah berlaku umum dan bersifat objektif sebagai suatu tindakan yang telah dirumuskan dalam norma sehingga bisa diuji dengan komponen iktikad baik, secara objektif maupun secara subjektif.

Secara objektif adalah apakah yang dilakukan advokat tersebut dinilai memiliki kepatutan dalam masyarakat dan secara subjektif apakah tindakan yang dilakukan advokat tersebut memiliki kejujuran dalam praktik penegakan hukum mengingat dalam UU Advokat disebutkan bahwa advokat adalah penegak hukum.

Fenomena yang terbaru adalah menggeser imunitas kepada impunitas. Adapun impunitas sendiri menurut kamus adalah pembebasan dari hukuman. Salah satu instrumen untuk menghindari bergesernya imunitas kepada impunitas adalah dengan politik memori yang menggunakan pendekatan merekam dan mengingat sebagai sebuah strategi kolektif tentang bagaimana kebenaran yang objektif dapat diperoleh dengan menegakkan keadilan.

Impunitas bukan hak yang dimiliki oleh advokat sebagai penegak hukum. Namun, hak itu adalah imunitas. Hak imunitas diberikan guna

21 Elba Damhuri, "Hak Imunitas Advokat", www.republika.co.id, diakses tanggal 19 September 2019. 
mendukung optimalnya peran dan tugas advokat dalam rangka penegakan hukum.

Hak imunitas diberikan kepada advokat sehubungan dengan peran dan tugas advokat sebagai penegak hukum. Selanjutnya obstruction of justice merupakan tindakan melawan hukum yang tentu saja tidak memiliki iktikad baik sehingga bila obstruction of justice terjadi dan hak imunitas berfungsi maka yang terjadi adalah impunitas.

\section{Hak imunitas advokat ditinjau dari pengaturan hukum positif di Indonesia}

Advokat dalam menjalankan profesinya memiliki hak imunitas atau kekebalan hukum dengan berpegang pada kode etika profesi namun yang menjadi sorotan disini ialah tolak ukur itikad baik yang dimaksud dalam pasal tersebut seperti apa, karena itikad baik yang dimaksud dalam pasal tersebut mempunyai arti yang sangat luas atau umum dimana hak kekebalan advokat bergantung dari itikad baik advokat tersebut.

Hak Imunitas (kekebalan hukum) pada advokat tidak hanya diatur dalam Undang-Undang Nomor 18 Tahun 2003, tetapi juga diatur dalam Kitab Undang-Undang Hukum Pidana juga mengatur tentang hal tersebut, terda pat dalam Pasal 50 KUHP dimana Pasal itu memuat tentang pengecualian hukum. Pasal ini menentukan pada prinsifnya orang yang melakukan suatu perbuatan meskipun itu melakukan tindak pidana akan tetapi karena dilakukan berdasarkan perintah undang-undang maka si pelaku tidak boleh di hukum. Asalkan perbuatan yang dilakukan tidak untuk kepentingan pribadi melainkan kepentingan umum. Jika karakter advokat memang advokat memang orang yang selalu menjankan tugasnya dengan baik, maka alasan pengahpusan pidana dapat berlaku baginya. Berdasarkan Pasal ini dapat dihat hubungannya dalam Undang Undang Advokat bahwa advokat mempunyai kekebalan hukum karena menjalankan tugas profesinya sesuai yang diatur dalam undangundang.

Menurut Pasal 54 KUHAP yang berbunyi guna kepentingan pembelaan tersangka atau terdakwa berhak mendapat bantuan hukum dari seorang atau penasehat hukum selama dalam waktu tingkat pemeriksaan, berdasarkan yang 
ditentukan oleh undang-undang ini. ${ }^{22}$ hak kekebalan hukum untuk tidak dapat dituntut baik secara perdata maupun pidana dalam menjalankan tugas profesinya dengan itikad baik dalam sidang pengadilan, hak kekebalan ini terkait dengan pengakuan bahwa advokat tidak diidentikan dengan kliennya oleh pihak yang berwenang atau masyarakat. Pengaturan tentang hak imunitas advokat dapat disimak dan pihami dengan lebih mendalam dalam Pasal 14 hingga Pasal 19 Undang-Undang Nomor 18 Tahun 2003, tepatnya pada Bab IV tentang hak dan kewajiban. Namun dalam Undang-Undang Nomor 18 Tahun 2003 pad a Pasal 16 tidak terdapat batasan-batasan itikad baik itu seperti apa, ketika sidang sudah selesai maupun saat sidang belum dimulai merupakan itikad baik untuk membela kepentingan klien. Pada Pasal 16 masih dapat dikaatakan rancu dan memiliki banyak perspektif dan siapapun memiliki cara menginterprestasikannya juga bisa menafsirkan apa saja.

Pro-kontra rancangan Undang-Undang Advokat mendapat begitu banyak dari beberapa pakar hukum di Indonesia. Peristiwa terbaru Munas Perhimpunan Indonesia (PERADI) di Makasar Maret lalu PERADI terbagi menjadi 3 kepemimpinan hal tersbut dikarenakan banyaknya terjadi masalah di dalam organisasi advokat dalam mengatur berlangsungnya organisasi tersebut, terlihat bahwa Undang-Undang Advokat sudah dapat dikatakan tidak sesuai dan perlu diadakannya revisi. Usulan RUU tentang Advokat yang diajukan oleh Asosiasi Organisasi Advokat ke DPR RI terlihat jelas bahwa Pasal-Pasal tentang hak imunitas tersebut yang tercantum dalam Pasal 14 sampai dengan Pasal 19 Undang-Undang Nomor 18 Tahun 2003 tentang Advokat tidak menjadi usulan organisasi advokat untuk Hak imunitas (kekebalan hukum) dibatasi menurut Pasal 74 KUHAP. Sebagaimana dalam Pasal 70 ayat (2), ayat (3), ayat (4), dan Pasal 71 yang dimana pengurangan kebebasan hubungan antara penasehat hukum dan tersangka, setelah perkara dilimpahkan oleh penuntut umum kepada pengadilan negeri untuk disidangkan, yang tembusan suratnya disampaikan kepada tersangka atau penasehat hukumnya serta pihak lain dalam proses. Hak advokat dalam Undang-Undang Nomor 18 Tahun 2003 tentang Advokat dapat dikatakan paling sentral dengan diaturnya hak

${ }^{22}$ Indonesia, Undang-undang Nomor 8 Tahun 1981 tentang Hukum Acara Pidana, Pasal 54 
kekebalan hukum untuk tidak dapat dituntut baik secara perdata maupun pidana dalam menjalankan tugas profesinya dengan itikad baik dalam sidang pengadilan, hak kekebalan ini terkait dengan pengakuan bahwa advokat tidak diidentikan dengan kliennya oleh pihak yang berwenang atau masyarakat. Pengaturan tentang hak imunitas advokat dapat disimak dan pihami dengan lebih mendalam dalam Pasal 14 hingga Pasal 19 Undang-Undang Nomor 18 Tahun 2003, tepatnya pada Bab IV tentang hak dan kewajiban. Namun dalam Undang-Undang Nomor 18 Tahun 2003 pada Pasal 16 tidak terdapat batasanbatasan itikad baik itu seperti apa, ketika sidang sudah selesai maupun saat sidang belum dimulai merupakan itikad baik untuk membelakepentingan klien.

Pada Pasal 16 masih dapat dikaatakan rancu dan memiliki banyak perspektif dan siapapun memiliki caramenginterprestasikannya juga bisa menafsirkan apa saja.Pro-kontra rancangan Undang-Undang Advokat mendapat begitu banyak dari beberapa pakar hukum di Indonesia. Peristiwaterbaru Munas Perhimpunan Indonesia (PERADI) di Makasar Maret lalu PERADI terbagi menjadi 3 kepemimpinan hal tersbut dikarenakan banyaknya terjadi masalah di dalam organisasi advokat dalam mengatur berlangsungnya organisasi tersebut, terlihat bahwa Undang-Undang Advokat sudah dapat dikatakan tidak sesuai dan perlu diadakannya revisi. Usulan RUU tentang Advokat yang diajukan oleh Asosiasi Organisasi Advokat ke DPR RI terlihat jelas bahwa Pasal-Pasal tentang hak imunitas tersebut yang tercantum dalam Pasal 14 sampai dengan Pasal 19 Undang-Undang Nomor 18 Tahun 2003 tentang Advokat tidak menjadi usulan organisasi advokat untuk menguatkan posisi advokat didalam menjalankan profesinya.

Oleh karena itu profesi advokat dengan gampang dan mudah ditafsirkan berbeda oleh aparat penegak hukum dalam hak ini Jaksa, hakim, dan Polisi yang dapat mengakibatkan lemahnya hak imunitas tersebut yang secara langsung akan mengganggu seorang advokat didalam menjalankan profesinya untuk kepentingan klien. Dalam Rancangan Undang-Undang Advokat ada 8 poin yang akan diusulkan yaitu fungsi, hak dan kewajiban, organisasi advokat, kedudukan dan wilayah kerja advokat, kode etik, pengangkatan sumpah atau janji dan pemberhentian, partisipasi masyarakat, Dewan Advokat Nasional, 
serta larangan dan ketentuan pidana. Dari kedepalan usulan tersebut hanya satu poin mengenai Dewan Advokat Nasional yang tidak diatur dalam UndangUndang Nomor 18 Tahun 2003 tentang Advokat, sehingga dapat dikatakan usulan lainnya tidak termasuk dalam kategori urgensi. Mengenai Dewan Advokat Nasional tidak urgensi karena dalam pembahasannya di pending. Di sisi lain, penjelasan dari Dewan Advokat Nasional yang diusulkan dapat ditafsirkan bahwa tugas-tugas yang diberikan dengan yang dilakukan oleh Organisasi Advokat saar ini. Oleh karena itu urgensi RUU Advokat yang sudah masuk dalam Pogram Legislasi Nasional tahun 2014 sampai saat ini sebaiknya menyusulkan poin-poin yang justru belum diatur dalam Undang-Undang Advokat saat ini.

\section{Penutup}

\subsection{KESIMPULAN}

1. Hak imunitas diatur dalam Pasal 16 UU Advokat dan diperkuat dengan putusan Mahkamah Konstitusi (MK) yang menyatakan bahwa hak imunitas ini berlaku, baik di dalam maupun di luar persidangan. Dalam hal ini, imunitas advokat selalu dibatasi oleh iktikad baik, yang didefinisikan dalam Penjelasan Pasal 16 UU Advokat, yaitu yang dimaksud dengan iktikad baik adalah menjalankan tugas profesi demi tegaknya keadilan berdasarkan hukum untuk membela kepentingan klien. Hak imunitas diberikan kepada advokat sehubungan dengan peran dan tugas advokat sebagai penegak hukum.

2. Hak imunitas atau kekebalan hukum tidak hanya diatur dalam Pasal 16 Undang-Undang Advokat mengenai hak imunitas seorang advokat, hak imunitas atau kekebalan hukum juga diatur dalam Pasal 50 KUHP, sedangkan mengenai pembatasan hak imunitas atau kekebalan hukum terdapat dalam Pasal 74 KUHAP.

\subsection{SARAN}


1.Agar seluruh aparat penegak hukum di Indonesia (Polisi,Jaksa, dan Hakim) benar-benar memperhatikan dan mengakui keberadaan hak imunitas seorang advokat. Kemudian dimasa yang akan datang advokat hendaknya membentuk suatu wadah tunggal, oleh karenanya pengaturan advokat secara limitatif hanya diatur dalam Undang-Undang Nomor 18 Tahun 2003.

\section{DAFTAR PUSTAKA}

\section{Buku}

Soehino, Ilmu Negara. (Yogyakarta:Liberty, 1998).

Farid, Zainal Abidin, Hukum Pidana. (Jakarta: Sinar Grafika, 1998).

Prasetyo, Teguh, Hukum dan Sistem Hukum Berdasarkan Pancasila. (Yogyakarta: Media Perkasa, 2013).

Prasetyo, Teguh, Keadilan Bermartabat Perspektif Teori Hukum. (Bandung: Nusa Media, 2015).

Marzuki, Peter Mahmud, Penelitian Hukum. (Jakarta: Kencana Prenada Media Group, 2011).

Muhammad, Abdul Kadir, Hukum dan Penelitian Hukum. (Bandung: PT Citra Aditya Bakti, 2004).

Sri Mamudji, Soerjono Soekanto, Penelitian Hukum Normatif. (Jakarta: Raja Grafindo Persada, 2004).

Marzuki, Peter Mahmud, Penelitian Hukum Edisi Revisi. (Jakarta: Kencana Media Group, 2006)

\section{Peraturan perundang-undangan}

Indonesia. Undang-Undang Dasar Negara Republik Indonesia Tahun 1945

Indonesia. Undang-Undang Republik Indonesia Nomor 8 Tahun 1981 tentang Hukum Acara Pidana

Indonesia, Undang-Undang Republik Indonesia Nomor 18 Tahun 2002 tentang Advokat

Indonesia, Undang-Undang Nomor 8 Tahun 2008 tentang Advokat 


\section{Internet}

Aziz, Abdul. "Melihat Hak Imunitas Advokat dalam Kasus Fredrich Yunadi”. www.tirto.id. Diakses tanggal 19 September 2019

Sahbani, Agus. "Akhirnya, Advokat Dapat Perlindungan di Luar Sidang”. www.hukumonline.com. Diakses tanggal 19 September 2019.

Damhuri, Elba. "Hak Imunitas Advokat", www.republika.co.id. Diakses tanggal 19 September 2019. 